\title{
Combined study of archaeomagnetism and Raman spectroscopy of experimentally burnt limestones from the middle-palaeolithic site of Pinilla del Valle (Madrid, Spain)
}

\author{
Ángel Carrancho, Susana E. Jorge-Villar, Laura Sánchez-Romero, Theodoros Karampaglidis
}

Ángel Carrancho

acarrancho@ubu.es

Área de Prehistoria, Dpto. Historia, Geografía y Comunicación, Plaza Misael Bañuelos S/N,

Universidad de Burgos, 09001 Burgos, Spain.

Susana E. Jorge-Villar

Área de Geodinámica Interna, Facultad de Educación, Universidad de Burgos, C/ Villadiego $\mathrm{n}^{\circ}$ 1, 09001 Burgos, Spain.

Susana E. Jorge-Villar

Laura Sánchez-Romero

Theodoros Karampaglidis

Centro Nacional de Investigación sobre la Evolución Humana (GENIEH), Paseo Sierra de Atapuerca, 3, 09002 Burgos, Spain.

\section{Laura Sánchez-Romero}

Doctorado Interuniversitario de Evolución Humana, Paleoecología del Cuaternario y Técnicas Geofisicas Aplicadas a la Investigación, Universidad de Burgos, Juan de Austria 1, 09001 Burgos, Spain.

BOL. SOC. GEOL. MEX. 2019

VOL. 71 NO. 2

P. $383-396$

http://dx.doi.org/10.18268/BSGM2018v70n2a9

Manuscript received: January 01, 2018

Corrected manuscript received: May 18, 2018

Manuscript accepted: May 28, 2018

\section{ABSTRACT}

Here we report the archaeomagnetic, rock-magnetic and Raman spectroscopy results of sample analysis from two types of limestones that were experimentally heated under controlled conditions. These lithologies have been commonly identified at the middle-palaeolithic sites of Descubierta Gave and Navalmaillo rock-shelter (Pinilla del Valle, Madrid, Spain). By means of a thermocouple system, maximum heating temperatures of $400-450{ }^{\circ} \mathrm{C}$ were recorded during one hour. The main goal was to characterize the variations in the magnetic mineralogy and (in)organic compounds, and to study the record of the Earth's magnetic field direction at the time of cooling. This allowed us to obtain a pattern that is potentially applicable to archaeological limestones in order to identify combustion structures at the site. All experiments were carried out on representative samples both before and after experimental heating. Before heating, both types of limestones were dominated by dolomite and calcite and as main iron oxides, goethite and magnetite. After heating, the original goethite persisted in samples heated to low temperatures $\left(<200{ }^{\circ} \mathrm{C}\right)$ whereas it transformed to haematite and/or magnetite in those heated to $450{ }^{\circ} \mathrm{C}$. Mineralogical alterations mostly focused on the outermost $1^{\mathrm{st}} \mathrm{cm}$ of depth. The neoformation of magnetite as intermediate step in the dehydration process of goethite to haematite has been barely documented and has palaeomagnetic implications. The mineralogical results obtained, their implications for the identification of fire at the site as well as potential applications to similar cases studies are discussed.

Keywords: iron oxides, experimental fires, geoarchaeology, hearths, Palaeolithic, thermal remanent magnetisation.

\section{RESUMEN}

Se presentan los resultados arqueomagnéticos, de propiedades magnéticas y espectroscopia Raman obtenidos de analizar muestras de dos tipos de calizas calentadas experimentalmente bajo condiciones controladas. Estas calizas han sido frecuentemente identificadas en los yacimientos de paleolítico medio de Cueva Descubierta y Abrigo de Navalmaíllo (Pinilla del Valle, Madrid, España). Mediante un sistema de termopares, se registraron temperaturas máximas de calentamiento de $400-450^{\circ} \mathrm{C}$ durante una hora. El objetivo es caracterizar las variaciones en la mineralogía feromagnética y los compuestos (in)orgánicos, así como estudiar el registro de la dirección del campo magnético terrestre en el momento del enfriamiento. Esto permitirá obtener un patrón extrapolable a las calizas arqueológicas de cara a identificar estructuras de combustión en el yacimiento. Los experimentos de ambas técnicas fueron realizados en muestras representativas de ambas litologías tanto antes como después de la quema experimental. Antes de la quema, ambos tipos de caliza estaban dominados por dolomita y calcita y, como principales óxidos de hierro, goetita y magnetita. Tras la quema, la goetita original pervivió en las muestras calentadas $<200{ }^{\circ} \mathrm{C}$ mientras que se transformó a hematites y/o magnetita en las calentadas en torno a $450^{\circ} \mathrm{C}$. Las alteraciones mineralógicas se centraron mayoritariamente en el $1^{\text {er }}$ $\mathrm{cm}$ de profundidad. La neoformación de magnetita como paso intermedio en el proceso de deshidratación de la goetita hacia hematites ha sido poco documentada y tiene implicaciones paleomagnéticas. Se discuten los resultados mineralógicos, sus implicaciones para la identificación de fuego en el yacimiento así como sus potenciales aplicaciones a casos de estudio similares.

Palabras clave: Óxidos de hierro, fuegos experimentales, geoarqueología, hogares, Paleolítico, magnetización termorremanente. 


\section{Introduction}

The palaeolithic archaeological sites of El Calvero de la Higuera are located in the Eastern part of the Central Iberian Range, in the karstic system of Pinilla del Valle (Madrid). The archaeo-palaeontological record recovered so far is providing detailed insights into the occupation and activity of Neanderthals in the center of the Iberian Peninsula during the Upper Pleistocene and its environmental conditions (e.g. Huguet et al., 2010; Márquez et al., 2013; Laplana et al., 2016). From the data available, possible traces of anthropic fire at the site is what archaeologists consider to be among the most interesting information. The occurrence of fire at middle-palaeolithic sites is not unusual but its identification is not straightforward since the evidence (e.g. charcoals, thermoaltered sediment and in the best cases, ashes) is usually scarce, ambiguous or poorly preserved. The analysis of the spatial distribution of two types of local limestone blocks forming circles at certain levels of the site tentatively suggests the possible existence of hearths. Beyond that, unequivocal fire evidence is really scarce and its identification based exclusively on macroscopic (visual) observations is fairly difficult.

The literature concerning the study of fire residues in prehistoric archaeological sites has considerably increased over the last years. Some of these studies have mainly focused on the positive identification of fire in the archaeological record which is particularly problematic in palaeolithic sites (e.g. Aldeias et al., 2012; Berna et al., 2012; Stahlschmidt et al., 2015). However, technological questions related to fire use and function such as type of fuel employed, temperatures achieved or potential usages have also acquired special attention in geo-archaeological research (e.g. Aldeias et al., 2016; Balbo et al., 2015; Braadbaart et al., 2012; Goldberg et al., 2012). These studies comprise the analyses of ashes, charred bones, stone implements of diverse lithologies or organic residues through the application of different geoarchaeological techniques such as Mössbauer spectroscopy, x-ray diffraction
(XRD), soil micromorphology or Fourier transform infrared spectroscopy (FTIR), among others (e.g. Munayco and Scorzelli, 2013; Reidsma et al., 2016; Schmidt et al., 2013, 2015, 2017; Wadley and Prinsloo 2014).

Magnetic methods are very sensitive to detect thermal alterations in archaeological or geological materials. Ferromagnetic minerals (mainly iron oxides and hydroxides), modify their magnetic properties upon heating and this can be easily detected with rock-magnetic and archaeomagnetic analyses (e.g. Evans and Heller 2003; Tauxe et al., 2010). Raman spectroscopy is a non-destructive technique with great potential to characterize the composition and internal structure of a compound. It may help to identify mineral and organic materials, polimorphs and isomorphs phases as well as mixture caracterizations (e.g. Griffith 1969; Lin-Vien et al., 1991; Edwards et al., 2005, 2007; De Gelder et al., 2007; Acosta-Maeda 2016). These techniques have a great potential to study multiple geoarchaeological questions but, to our knowledge, their combined use is still quite limited. The main aim of this study was to characterize with archaeomagnetism, rock-magnetism and Raman spectroscopy how these two types of limestones transform when heated experimentally under controlled temperature conditions. This experimental pattern may be useful to compare with archaeological limestones in a second stage of the research to positively identify fire at the archaeological site.

\section{Materials and methods}

\subsection{MATERIALS AND EXPERIMENTAL BURNING}

Two types of local upper cretaceous limestones commonly documented at the archaeological excavations were used in the experiment: Navalmaíllo limestone (NL) and Cueva Descubierta limestone (CDL). The bed rock deposits of the Calvero de la Higuera karst system, where the archaeological sites are located, are composed of 
marine shallow shelf sediments of dolomites with intercalated marls. The marine cyclic sequence is closely related to important cretaceous eustatic base level changes. The sequence is characterised by three repetitive patterns of different rock types (strata). The lower one is composed by marls, the intermediate by carbonates and the upper with strongly cemented carbonates (Pérez González et al., 2010). Each strata respond differently to weathering and erosion. The intermediate carbonate strata are the most affected by weathering processes such as dissolution, carbonation and oxidation (Karampaglidis et al., 2015). The last one gives the affected rocks a reddish-brown coloration on the surface which crumbles easily and weakens the rock. Twelve hand-block samples of both type of limestones (7 NL and $5 \mathrm{CDL}$ ) were collected from the surrounding of the archaological sites in order to carry out the experimental heating.
The experimental burning was carried out in early summer 2013 at Celadilla-Sotobrín, Burgos, Spain ( $42^{\circ} 27^{\prime} \mathrm{N}$ Lat., $3^{\circ} 43^{\prime} \mathrm{W}$ Long.). In order to monitor the temperature variations with time, a K-type thermocouple system was carefully located on the most external part of selected blocks of both types of limestones which were circularly distributed (Figure 1a to 1d). An additional thermocouple (T3) was located in the substrate of the center of the hearth just for control. Wood fuel (cf. Quercus ilex) was used during burning and temperature readings were taken every five minutes during one hour. The highest temperatures recorded by the different themocouples varied between 400 and $450{ }^{\circ} \mathrm{C}$ as is shown in Figure $2 \mathrm{a}$ and $2 \mathrm{~b}$ ). Thermocouple T3 (central part of the hearth) only reached $100{ }^{\circ} \mathrm{C}$ because it was located at $2 \mathrm{~cm}$ of depth of the substrate. The very humid conditions of the substrate before burning together with the isolat-
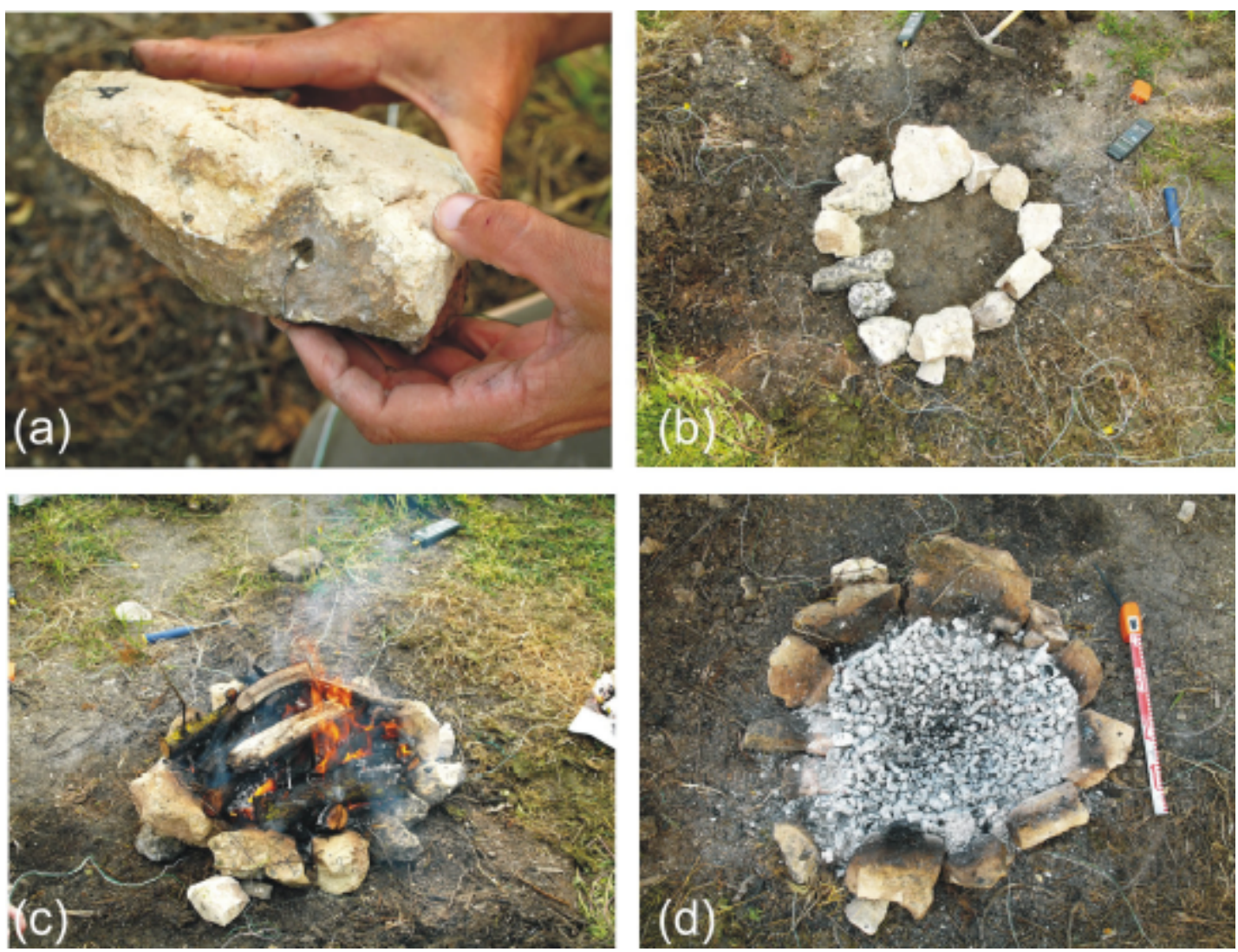

Figure 1 Main steps followed during the experimental burning. (a) Detail showing the location of a thermocouple in a limestone block; (b) Circular spatial arrangement of the limestones before burning; (c) Moment of the burning; (d) Hearth generated after burning. 

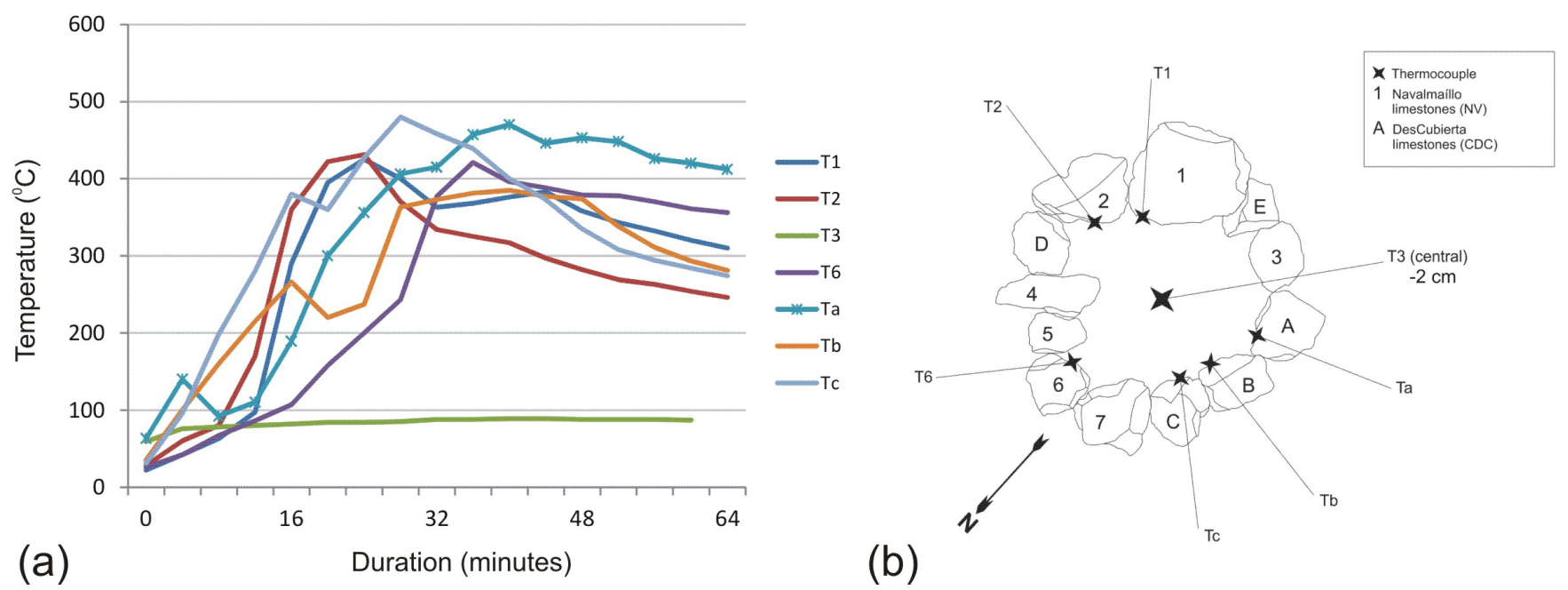

Figure and thermocouples in the hearth according to the legend (numbers: Navalmaíllo limestones; letters: Descubierta limestones).

ing effect generated by the ashes once they cover the surface avoiding heat penetration with depth, also explain why T3's temperatures are strikingly low. Anyway, this is irrelevant for the goal of the study because the important temperatures are those specifically referred to the limestones blocks (Figure $2 \mathrm{a}$ and $2 \mathrm{~b}$ ).

\subsection{SAMPLING}

16 cylindrical cores from both types of limestones (9 from NL and 7 from CDL) were collected for archaeomagnetic analysis using a portable electrical drill with a watercooled diamond bit, following the standard palaeomagnetic sampling procedure. The in-situ azimuth and dip of the drilled cores were measured using a compass coupled to a core orienting device. When possible, each core was subsampled to obtain more than one specimen $\left(10 \mathrm{~cm}^{3}\right)$ in order to study how heat penetration varied as a function of depth (from the outermost part to the inner of the rocks) and how it affected the magnetic properties. Outer specimens $(0-2 \mathrm{~cm})$ were labelled as " $x . a$ " and inner specimens (2-4 cm) as " $x . b$ ". The sample set was composed of 22 specimens (17 " $a$ " and 5 " $b$ "). Samples for Raman spectroscopy analyses were obtained specifically from representative archaeomagnetic cores. Two complete cores of both types of limestones as well as three other samples obtained from three additional cores longitudinally sliced were used for Raman analyses in order to study the mineralogical variations.

\subsection{LABORATORY ANALYSES}

All archaeomagnetic and rock-magnetic analyses were carried out at the laboratory of palaeomagnetism of Burgos University, Spain. Archaeomagnetic analysis comprised the stepwise alternating field $(\mathrm{AF})$ or thermal $(\mathrm{TH})$ demagnetisation of the natural remanent magnetisation (NRM). The NRM was measured using a 2G SQUID magnetometer (noise level $5 \times 10^{-12} \mathrm{Am}^{2}$ ). The $\mathrm{AF}$ demagnetisation was carried out in 20 steps up to a maximum peak field of $100 \mathrm{mT}$, with the demagnetisation unit of the $2 \mathrm{G}$ magnetometer. Thermal (TH) demagnetisation was performed in 18 steps up to $600{ }^{\circ} \mathrm{C}$ using a TD48-SC(ASC) thermal demagnetiser. In order to monitor mineralogical alterations induced by heating the magnetic susceptibility was measured at room temperature after each thermal demagnetisation step with a KLY-4 susceptometer (AGICO; noise level $3 \times$ 
$\left.10^{-8} \mathrm{SI}\right)$. The characteristic remanent magnetisation (ChRM) direction of all specimens was determined though principal components analysis (Kirschvink, 1980), including between five to eight steps of demagnetisation. The mean archaeomagnetic direction was computed following Fisher's (1953) statistics.

In order to characterize the magnetic remanence carriers and evaluate the stability of the magnetic signal various rock-magnetic analyses were undertaken with the aid of a Magnetic Measurements Variable Field Translation Balance (MM_VFTB). These included the measurement of progressive isothermal remanence acquisition curves, hysteresis loops $( \pm 1 \mathrm{~T})$, backfield coercivity curves and the study of the dependence of magnetisation variation with temperature (thermomagnetic curves) up to $700{ }^{\circ} \mathrm{C}$ in air. These analyses were carried out on representative samples $(\sim 450 \mathrm{mg})$ of both lithologies both before and after burning. VFTB results were analysed and dia/paramagnetic signal removed using the RockMagAnalyzer software of Leonhardt (2006).

Additionally, progressive incremental partial thermomagnetic curves were performed on representative samples from both types of limestones in order to estimate the temperatures studying their reversibility. This information might be useful to correlate with the thermocouples' readings to have an additional check of temperatures. The approach basically is the same to that proposed by Hrouda et al. (2003), who used progressive susceptibility versus temperature measurements as palaeotemperature indicator quantifying magnetomineralogical changes induced during laboratory heating. This alteration can be estimated as $A_{30}=100\left(\mathrm{j}_{30}-\mathrm{J}_{30}\right) / \mathrm{J}_{30}$, where $\mathrm{j}_{30}$ and $\mathrm{J}_{30}$ are the magnetisation on the cooling and heating curves at $30^{\circ} \mathrm{C}$, respectively (Hrouda et al., 2003). These analyses were carried out on powdered sample $(\sim$ $450 \mathrm{mg}$ ) from both types of limestones in $50{ }^{\circ} \mathrm{C}$ incremental steps from 200 to $700{ }^{\circ} \mathrm{C}$.

Raman spectroscopic analyses were done using a Thermo scientific DXR micro-Raman spectrometer with $780 \mathrm{~nm}$ laser wavelength. Typically, 60 to 80 accumulations at 10 seconds exposure time were collected, using 0.5 to $1 \mathrm{~mW}$ laser power to avoid mineralogical changes because of laser heating. These analyses were carried out at the CENIEH (Burgos) in representative samples of both lithologies before and after burning.

\section{Results and discussion}

\subsection{MINERALOGICAL GHARACTERIZATION}

Initial natural remanent magnetisation $\left(\mathrm{NRM}_{0}\right)$ intensities after burning are between $9.85 \times 10^{-5}$ $\mathrm{A} / \mathrm{m}$ and $1.02 \mathrm{~A} / \mathrm{m}$, whereas magnetic suscepti-
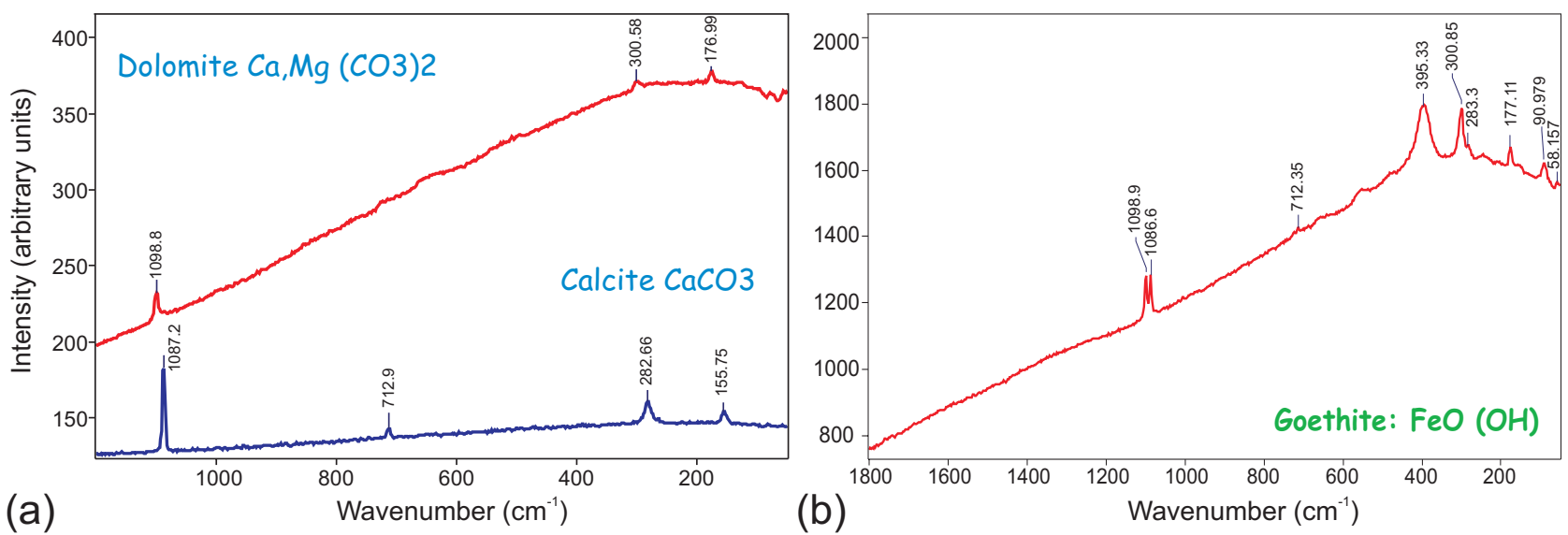

(b) 
bility values oscillate between $6.92 \times 10^{-7}$ and 7.37 x $10^{-4}$ SI. Fourteen out of twenty-two specimens $(63 \%)$ showed diamagnetic (negative) susceptibilities indicating that concentration of ferromagnetic minerals (s.l.) for various samples even after burning was rather low.

Rock-magnetic experiments carried out on pre-burning pilot samples indicate the coexistence of magnetite (determined from the thermomagnetic curves with Gurie temperatures, $\left(T_{C} \sim 580\right.$ ${ }^{\circ} \mathrm{C}$ ) with a high-coercivity phase which in the IRM acquisition curves (not shown here) does not reach saturation at fields of $1 \mathrm{~T}$ (haematite and/or goethite). Raman analyses indicate that both types of limestones are mostly composed of calcite and dolomite, and also show that the high-coercivity ferromagnetic phase is goethite (Figure $3 \mathrm{a}$ and $3 \mathrm{~b}$ ). The magnetic properties of post-burning samples are related to the thermal impact suffered regardless of the type of limestone analyzed. Archaeomagnetic data indicate that goethite is still present in several outer specimens $(0-2 \mathrm{~cm})$. The low magnetization intensity values, the hardness upon $\mathrm{AF}$ demagnetisation (e.g. Figure 4a) and particularly the loss of up to $80-90 \%$ of the NRM after the $100-120^{\circ} \mathrm{C}$ thermal demagnetisation step is clear-

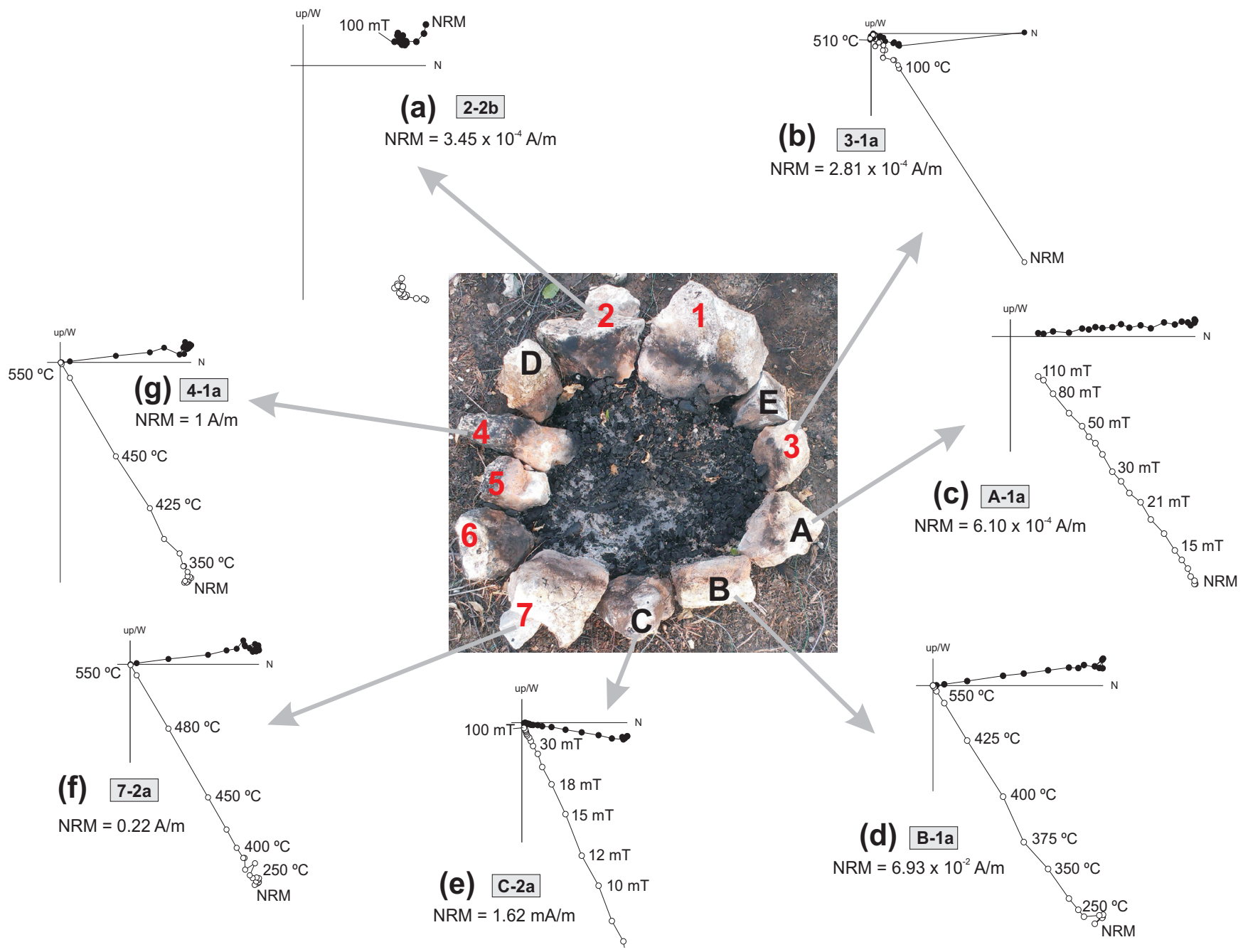

Figure 4 Representative NRM orthogonal demagnetisation diagrams of both types of limestones after the experimental heating. Sample code, intensities (NRM) and demagnetisation steps are indicated. Both types of limestones are denoted with black letters (CDL) and red number $(\mathrm{NL})$, respectively. 
ly indicative of this (e.g. Figure 4b). The survival of this phase has also been confirmed by Raman analyses in the "fresh zone" (1-1.5 cm depth) on various post-burning samples (Figure 5). This result indicates that the heating experienced by some of these limestones was not sufficient to transform the goethite originally present. Nevertheless, the dominant iron oxide identified with Raman spectroscopy in the outermost zone $(0-1 \mathrm{~cm}$ depth $)$ on both types of limestones after heating was haematite (figures 5 and 6). This would explain the characteristic reddish colour observed in many samples which gradually dissipated with depth. Another major compound identified with Raman spectroscopy in the post-burning limestones was carbon, which was responsible for the dark colours (Figure 6). As far as the mineral magnetic analyses are concerned, the main magnetic carrier identified in the post-burning samples was magnetite. This has been particularly observed in the thermomagnetic curves with $T_{C}$ near to $580^{\circ} \mathrm{C}$ but also in many

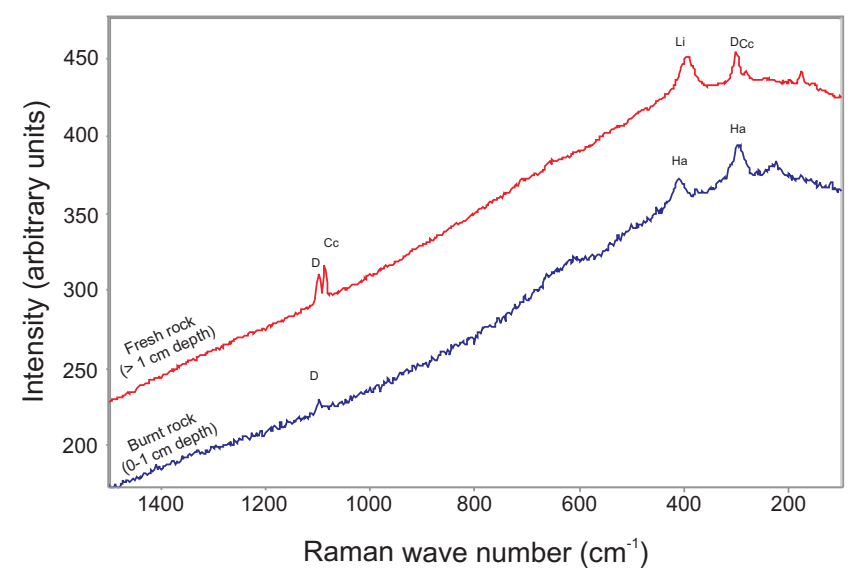

Figure 5 Raman spectroscopic results of a representative limestone after burning. Red: fresh rock (unburnt; $>1 \mathrm{~cm}$ depth) and blue: burnt rock (0-1 cm depth). D: Dolomite; Cc: calcite; Ha: haematite; Li: limonite.
NRM orthogonal demagnetisation diagrams (Figure $4 \mathrm{c}$ to $4 \mathrm{~g})$. Haematite, however, was not clearly identified with rock-magnetic analyses because its concentration was much lower than that of magnetite. Considering that magnetite is around 200 times more magnetic than haematite (Evans and Heller, 2003), haematite's magnetic signal is completely masked by magnetite. Moreover, haematite formed from the dehydration of goethite is generally superparamagnetic and does not carry remanence (Dunlop and Özdemir, 1997). This is why magnetic analyses failed to detect it conversely to Raman spectroscopy. The interesting fact from the methodological point of view is that these results show the complementarity of both methods in the mineralogical characterization of these samples.

\subsection{REVERSIBILITY OF PARTIAL THERMOMAGNETIC GURVES AND TEMPERATURES}

Partial thermomagnetic curves were carried out on representative post-burning samples to study their reversibility following the method proposed by Hrouda et al. (2003) to infer heating temperatures. The assumption relies on the fact that if the sample reached a given temperature in the past, it should exhibit thermomagnetic reversibility (coincidence between heating and cooling cycles) when heated again in the laboratory to the same temperature. Figure 7 illustrates partial thermomagnetic incremental curves of the limestone sample 4.1 (NV limestone). The other type of limestone (CDC) behaves exactly the same as we outline below. A complete thermomagnetic curve of this sample in a single run up to $700^{\circ} \mathrm{C}$ shows its irreversibility, with the heating and cooling cycles clearly different (Figure 7a). The partial thermomagnetic curves from $200^{\circ} \mathrm{C}$ until $400^{\circ} \mathrm{C}$, exhibit total reversibility with both heating and cooling cycles being almost coincident. For clarity, only the partial curve until $400^{\circ} \mathrm{C}$ is shown in Figure $7 \mathrm{~b}$. 

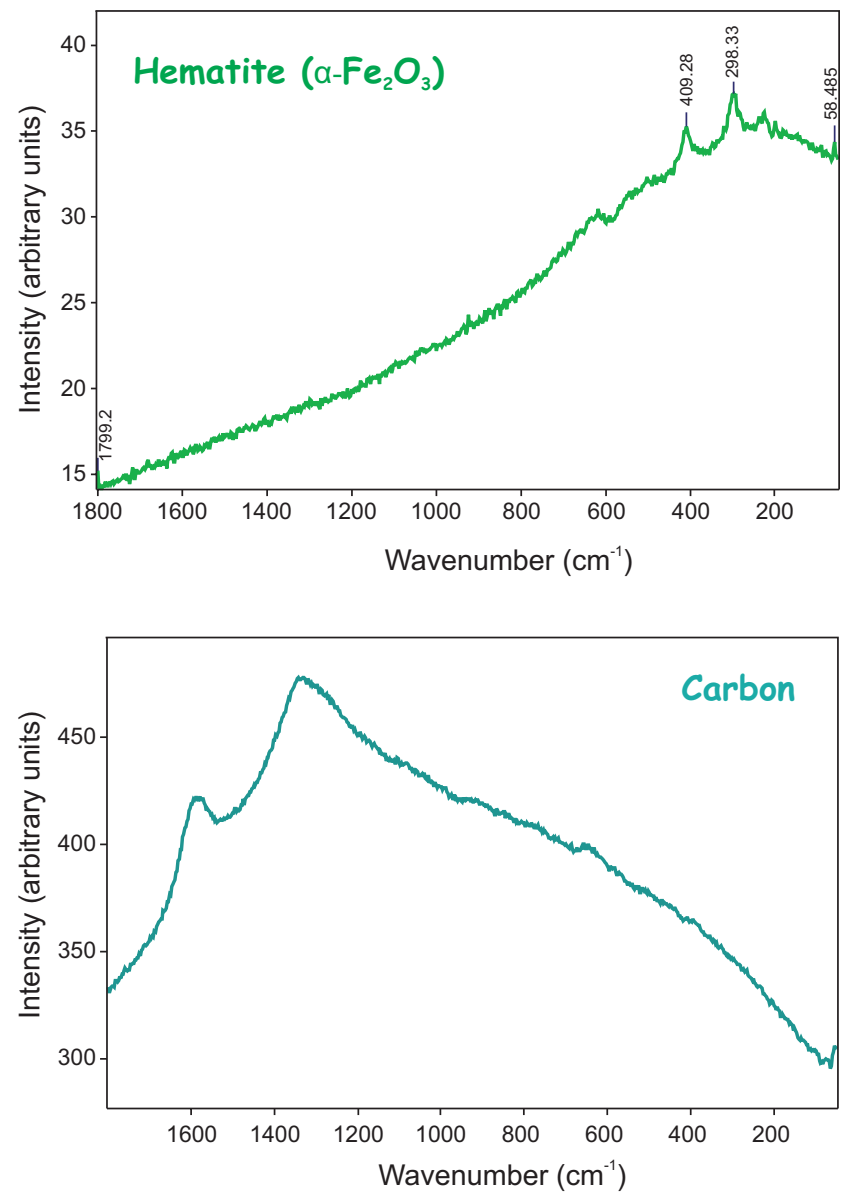

\section{Raman - postburnt samples}

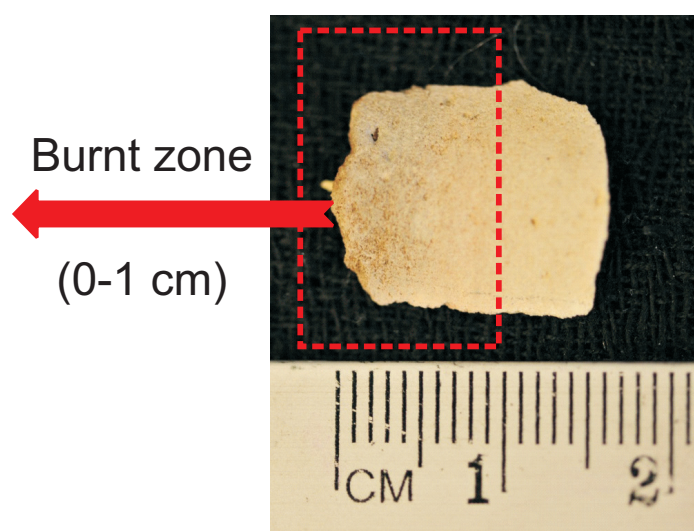

Figure 6 Raman spectra of the "burnt zone" (0-1 cm depth) of a limestone after burning showing the occurrence of haematite and carbon.

However, when the sample is heated in the laboratory to $450^{\circ} \mathrm{C}$ and over, the cycles differ showing irreversibility (Figure 7c to 7e). This irreversibility is even more pronounced at higher temperatures and indicates that a mineralogical transformation is taking place. It is most probably related with the formation of haematite because the cooling cycles exhibit lower intensities that their respective heating runs. The heating alteration index calculated shows that the alteration (formation of haematite) starts from $400-450^{\circ} \mathrm{C}$ (Figure 7f). This data suggest that this limestone did not exceed a heating temperature over $450^{\circ} \mathrm{C}$, which fits quite well with the temperature data recorded by the thermocouples (Figure 2). It is not the scope of this paper to discuss the limits of this method (for details, see
Hrouda et al., 2003), however, it has been successfully applied to a wide variety of burnt archaeological and experimental recreated materials as a palaeotemperature indicator (e.g. Carrancho and Villalaín, 2011; Carrancho et al., 2016; Kapper et al., 2014).

\subsection{DIRECTIONAL STABILITY OF NRM}

An archaeomagnetic study was carried out in order to assess the suitability of these limestones to record the Earth's magnetic field (EMF) direction under similar burning conditions (1 hour and maximum temperatures of $\sim 450^{\circ} \mathrm{C}$ ). This information combined with rock-magnetic and Raman spectroscopy data is very useful to obtain a pattern 

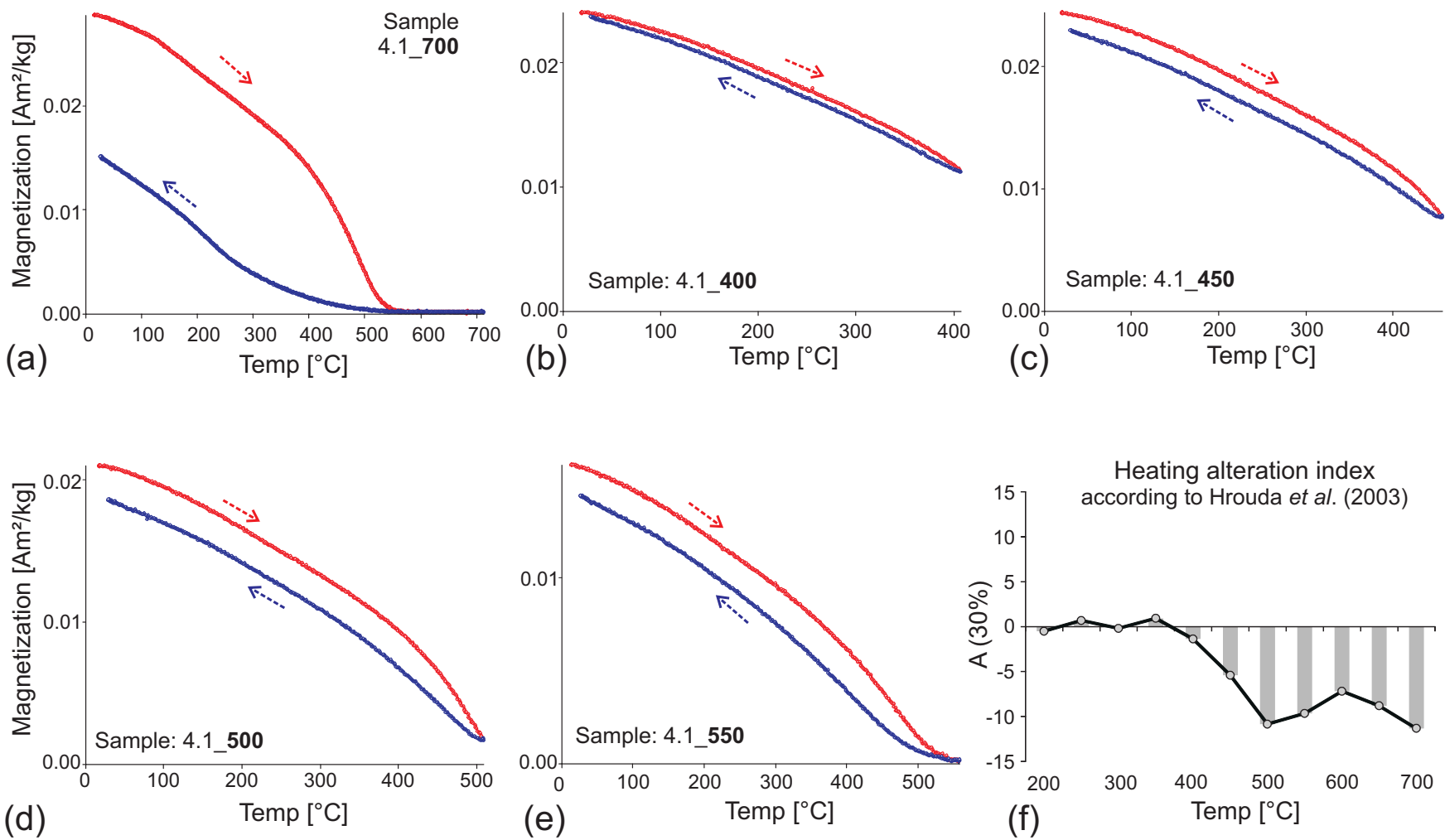

Figure 7 (a) High-temperature thermomagnetic curve (magnetisation vs. temperature) up to $700{ }^{\circ} \mathrm{C}$ of the limestone sample 4.1 after the experimental heating. (b-e) Partial thermomagnetic curves in $50{ }^{\circ} \mathrm{C}$ incremental steps from $200{ }^{\circ} \mathrm{C}$ to $700{ }^{\circ} \mathrm{C}$ carried out on an additional fragment of the sample 4.1. For clarity, panels b-e only show steps from $400{ }^{\circ} \mathrm{C}$ to $550^{\circ} \mathrm{C}$. Heating (cooling) cycles are plotted in red (blue) with their respective arrows. Sample code and magnetisation intensity values are also shown. (f) Histogram showing the variation in the alteration index of individual heating/cooling runs of 4.1 limestone sample following Hrouda's et al. (2003) method. See section 3.2 for explanation.

potentially applicable to the archaeological limestones in upcoming campaings. As the EMF direction for the time and place of burning is known (Dec: $358.5^{\circ} /$ Inc.: $57.5^{\circ}$; according to the International Geomagnetic Reference Field, IGRF11), it is worth studying how efficiently these limestones recorded it as well as if they generated distinctive properties with respect to their unburnt counterparts.

Figure $4 \mathrm{a}$ to $4 \mathrm{~g}$ illustrates representative orthogonal NRM demagnetisation diagrams for both types of limestones after burning. The variation in the intensities of magnetisation (NRM) appears to be up to 4 orders of magnitude. It is clear that mineralogical transformations induced by heating were much more significant in some blocks than in others irrespective of the type of limestone in- volved. During the field experiment, most wood fuel accumulated around blocks B, C, 7, 6 and 4 (Figure 4), coinciding with the highest temperatures recorded.

Samples from these blocks were indeed those with the highest intensities of magnetisation. Heating not only significantly increased the concentration of magnetite in comparison with the pre-burning samples but also among the post-burning ones. At the same time, samples which did not reach high enough temperatures (or during enough time), retained the pre-burning goethite phase (e.g. Figure $4 \mathrm{a}$ and $4 \mathrm{~b}$ ). Otherwise, they would have altered to haematite and/or magnetite. Conversion of goethite to haematite proceeds by dehydration which depending on topology, water content and other factors, may takes place from $200-250^{\circ} \mathrm{C}$ 
(Dekkers, 1990). However, some authors have identified a spinel phase of near magnetite composition as an intermediate product during this conversion (e.g. Özdemir and Dunlop, 2000) in a similar temperature range as our experiment. In any case, for archaeomagnetic purposes, those samples carrying goethite were not considered in the calculation of the EMF direction due to their unsuitability to determine the characteristic remanent magnetization (ChRM) direction (e.g. figure $4 \mathrm{a}$ and $4 \mathrm{~b})$.

In order to calculate the ChRM direction and obtain a mean archaeomagnetic direction some selection criteria were established in both types of limestones in relation to the observed magnetic properties and the structure and directional stability of the NRM. The most heated samples produced more magnetite and consequently exhibited the highest intensities, stable, univectorial NRM demagnetisation diagrams and reproducible directions. Only these specimens from both types of limestones were considered suitable and selected to perform the archaeomagnetic study. After removing a secondary viscous palaeomagnetic component (up to $10-12 \mathrm{mT}$ in $\mathrm{AF}$ diagrams and up to $200-250^{\circ} \mathrm{C}$ in $\mathrm{TH}$ diagrams), the ChRM direction was determined from 250 to $580^{\circ} \mathrm{C}$. A stable normal polarity component going towards the origin of the diagrams was systematically observed in these specimens (Figure. 4c to $4 \mathrm{~g})$. Figure 8 shows how the mean archaeomagnetic direction obtained and calculated only with " $a$ " $(0-2 \mathrm{~cm})$ specimens perfectly matched the expected direction. These samples faithfully recorded the EMF direction at the time of burning through the acquisition of thermochemical remanent magnetisation (TCRM) instead of a thermal remanent magnetisation (TRM) because heating temperatures were lower than Curie temperature of magnetite $\left(580^{\circ} \mathrm{C}\right)$. Any ferromagnetic (s.l.) mineral will acquire a TCRM under the simultaneous circumstances of slow cooling and volume growth or phase change below its Curie temperature (Dunlop and Özdemir, 1997). Since TCRM is acquired during initial cooling, there is no doubt about directional fidelity (Dunlop and Özdemir, 1997: page 410), thus enabling a faithfull (directional) archaeomagnetic dating. However, a TCRM would bias the outcome of palaeointensity experiments because only samples carrying TRM are suitable for absolute palaeointensity determinations (Tauxe et al., 2010). Recently, Carrancho and Villalaín (2011) reported a combined record of a TRM and a TCRM on magnetite-bearing burnt samples from the surface of an experimental hearth. Because of the temperatures achieved, which were also recorded with thermocouples, samples from the central area of the hearth $>600$ ${ }^{\circ} \mathrm{C}$ ) recorded a full TRM whereas peripheral samples (heated up to $300{ }^{\circ} \mathrm{C}$ ) carried a TCRM. Calvo-Rathert et al. (2012) studied these materials and demostrated using two different palaeointensity methods that only burnt sediments carrying a TRM were reliable recorders of the geomagnetic field strenght. As far as possible, archaeomagnetic sampling of similar structures should focus on those areas showing clear signs of high temperature heating. Furthermore, it has been also demonstrated with actualistic experiments that heating

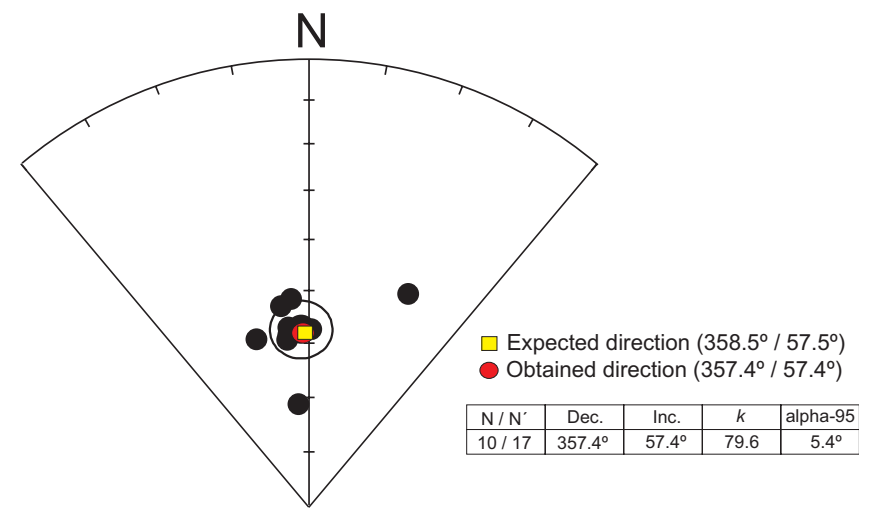

Figure 8 Stereoplot showing the mean archaeomagnetic direction obtained (red circle) and the expected direction (yellow square). Archaeomagnetic directional results are shown with their corresponding Fisher (1953) statistical parameters. $\mathrm{N}=$ samples considered for calculation; $\mathbf{N}^{\prime}=$ total number of samples processed; Dec = declination; Inc = inclination, $k$ and $a 95=$ precision parameter and $95 \%$ confidence limit of characteristic remanent magnetisation, respectively. 
of kilns, hearths or other recreated archaeological materials is always inhomogeneous with very significant temperature variations (e.g. Morales et al., 2011; Carrancho et al., 2014; Calvo-Rathert et al., 2012; Mallol et al., 2013). This reinforces the idea that archaeomagnetic sampling must be the most systematic as possible covering all parts of the structure.

These results show that under similar heating conditions to those reported here, these limestones may record the EMF direction. A distinctive magnetic signal in terms of intensity of magnetisation, directional NRM stability and mineralogical transformations was generated. Its combination with Raman spectroscopy data as well as archaeological observations (e.g. reddening, charcoal and so on) might be used as a criterion to identify fire at Pinilla del Valle sites or similar palaeolithic assemblages. The combined use of Raman spectroscopy and archaeomagnetic analyses is still far from being used extensivelty in geoarchaeology, although some works have successfully explored their applications together (e.g. Aidona et al., 2008; Rodriguez-Ceja et al., 2009). The mineralogical results reported here combining these techniques have defined a pattern which can be extrapolated to archaeological limestones in order to identify anthropic fire.

\section{Conclusions}

The mineralogical transformations induced by experimental heating of two types of limestones from Pinilla del Valle sites were studied with a combination of archaeomagnetism and Raman spectroscopy. Both types of limestones before burning were dominated by dolomite and calcite and the main iron oxides identified were goethite and magnetite. After burning, the original goethite persisted in samples heated to low temperatures $\left(<200{ }^{\circ} \mathrm{C}\right)$ whereas it transformed to haematite and/or magnetite in those heated to $450{ }^{\circ} \mathrm{C}$. Mineralogical alterations mostly focused on the outer- most $1^{\text {st }} \mathrm{cm}$ of depth where colour alterations were most pronounced, ranging from red (haematite) to black(carbon) as confirmed by Raman data. Archaeomagnetic results show that under similar burning conditions ( 1 hour; maximum temperatures $\sim 450^{\circ} \mathrm{C}$ ) these limestones may record the direction of the Earth's magnetic field. The main magnetic features observed from these mineralogical changes are increases of up to 4 orders of magnitude in the magnetisation intensities and unidirectional NRM magnetisation diagrams.

\section{Acknowledgements}

This research has been carried out with the finantial support of Junta de Castilla y León (projects BU066U16 and BU235P18) and the European Fund for Economic and Regional Development (FEDER). Raman analyses were performed in the Archaeometry laboratory at CENIEH facilities with the collaboration of CENIEH staff. We acknowledge Federico Alegre for the facilities given to carry out the experiment and his invaluable help during sampling. Special thanks are also due for the detailed comments of two referees who significantly improved the manuscript.

\section{References}

Acosta-Maeda, T. E., 2016, Raman spectroscopy for planetary exploration and characterization of extraterrestrial materials: Honolulu, USA University of Hawaii at Manoa, tesis doctoral, $152 \mathrm{p}$.

Aidona, E., Scholger, R., Mauritsch, H. J., Perraki, M., 2008, Remanence acquisition in a Roman-style gold furnace: Physics and Chemistry of the Earth, 33, 438-448.

Aldeias, V., Goldberg, P., Sandgathe, D., Berna, F., Dibble, H. L., McPherron, S. P., Turq, A., Rezek, Z., 2012, Evidence for Neandertal use of fire at Roc de Marsal (France): Journal of Archaeological Science, 39, 2414-2423. 
Aldeias, V., Dibble, H. L., Sandgathe, D. M., Goldberg, P., McPherron, S. P., 2016, How heat alters underlying deposits and implications for archaeological fire features: a controlled experiment: Journal of Archaeological Science, 67, 64-79.

Balbo, A. L., Cabanes, D., García-Granero, J. J., Bonet, A., Ajithprasad, P., Terradas, X., 2015, A microarchaeological approach for the study of pits: Environmental Archaeology 20, 390-405.

Berna, F., Goldberg, P., Horwitz, L.K., Brink, J., Holt, S., Bamford, M., Chazan, M., 2012, Microstratigraphic evidence of in situ fire in the Acheulean strata of Wonderwerk Cave, Northern Cape province, South Africa: Proceedings of the National Academy of Sciences, 109, 1215-1220.

Braadbaart, F., Poole, I., Huisman, H.D.J., Os, B. van, 2012, Fuel, Fire and Heat: an experimental approach to highlight the potential of studying ash and char remains from archaeological contexts: Journal of Archaeological Science 39, 836-847.

Calvo-Rathert, M., Carrancho, Á., Stark, F., Villalaín, J.J., Hill, M., 2012, Are burnt sediments reliable recorders of geomagnetic field strength?: Quaternary Research, 77, 326-330.

Carrancho, Á., Villalaín, J. J., 2011, Different mechanisms of magnetisation recorded in experimental fires: Archaeomagnetic implications: Earth Planetary Science Letters, 312, 176-187.

Carrancho, Á., Morales, J., Goguitchaichvili, A., Alonso, R., Terradillos, M., 2014, Thermomagnetic monitoring of lithic clasts burned under controlled temperature and field conditions. Implications for archaeomagnetism: Geofísica Internacional, $53,473-490$.

Carrancho, Á., Herrejón Lagunilla, Á., Vergès, J.M., 2016, Three archaeomagnetic applications of archaeological interest to the study of burnt anthropogenic cave sediments: Quaternary International, 414, 244-257.

De Gelder, J., De Gussem, K., Vandenabeele, P., Moens, L., 2007. Reference database of Raman spectra of biological molecules: Journal of Raman Spectroscopy, 38, 1133-1147.

Dekkers, M.J., 1990, Magnetic properties of natural goethite-III. Magnetic behaviour and properties of minerals originating from goethite dehydration during thermal demagnetization: Geophysical Journal International, 103, 233-250.

Dunlop, D., Özdemir, Ö., (1997), Rock Magnetism. Fundamentals and Frontiers: New York, Cambridge University Press, 573 p.

Edwards, H. G. M., Villar, S. E. J., Jehlicka, J., Munshi, T., 2005, FT-Raman spectroscopic study of calcium-rich and magnesiumrich carbonate minerals: Spectrochimica Acta Part A: Molecular and Biomolecular Spectroscopy, 61, 2273-2280.

Edwards, H. G. M., Villar, S. E. J., Pullan, D., Hargreaves, M. D., Hofmann, B. A., Westall, F., 2007, Morphological biosignatures from relict fossilised sedimentary geological specimens: a Raman spectroscopic study: Journal of Raman Spectroscopy, 38, 1352-1361.

Evans, M.E., Heller, F., (2003), Environmental Magnetism: Principles and Applications of Environmagnetics: San Diego, Academic Press, CA, USA, 299 p.

Fisher, R.A., 1953, Dispersion on a sphere: Proceedings of the Royal Society A: Mathematical, Physical and Engineering Sciences, 217, 295-305.

Goldberg, P., Dibble, H., Berna, F., Sandgathe, D., McPherron, S. J. P., Turq, A., 2012, New evidence on Neandertal use of fire: Examples from Roc de Marsal and Pech de l'Azé IV: Quaternary International, 247, 325-340.

Griffith, W.P., 1969, Raman spectroscopy of minerals: Nature, 224 (5216), 264-266. 
Hrouda, F., Müller, P., Hanák, J., 2003, Repeated progressive heating in susceptibility vs. temperature investigation: a new palaeotemperature indicator?: Physics and Chemistry of the Earth, 28, 653-657.

Huguet, R., Arsuaga, J.L., Pérez-González, A., Arriaza, M.C., Sala-Burgos, M.T.N., Laplana, G., Sevilla, P., García-García, N., Álvarez-Lao, D., Blain, H.A., Baquedano, E., 2010, Homínidos y hienas en el Calvero de la Higuera (Pinilla del Valle, Madrid) durante el Pleistoceno Superior. Resultados preliminares: Zona Arqueológica 13, 444-458.

Kapper, K.L., Anesin, D., Donadini, F., Angelucci, D.E., Cavulli, F., Pedrotti, A., Hirt, A.M., 2014, Linking site formation processes to magnetic properties. Rock- and archeomagnetic analysis of the combustion levels at Riparo Gaban (Italy): Journal of Archaeological Science, 41, 836-855.

Karampaglidis, T., Benito-Calvo, A., PérezGonzález, A., 2015, Geomorphology of the Lozoya river drainage basin area (Community of Madrid, Spanish Central System): Journal of Maps, 11, 342-353.

Kirschvink, J.L., 1980, The least-squares line and plane and the analysis of paleomagnetic data: Geophysical Journal Royal Astronomical Society 62, 699-718.

Laplana, C., Sevilla, P., Blain, H.A., Arriaza, M.C., Arsuaga, J.L., Pérez-González, A., Baquedano, E., 2016, Cold-climate rodent indicators for the Late Pleistocene of Central Iberia: New data from the Buena Pinta Cave (Pinilla del Valle, Madrid Region, Spain). Comptes Rendus Palevol, 15, 696-706.

Leonhardt, R., 2006, Analyzing rock magnetic measurements: The RockMagAnalyzer 1.0 software: Computer \& Geosciences, 32, $1420-1431$
Lin-Vien,D., Golthup, N.B., Fateley, W. G., Grasselli, J.G., 1991, The handbook of infrared and Raman characteristic frequencies of organic molecules: Amsterdam, the Netherlands, Elsevier, 503 p.

Mallol, G., Hernández, G.M., Cabanes, D., Machado, J., Sistiaga, A., Pérez, L., Galván, B., 2013, Human actions performed on simple combustion structures: An experimental approach to the study of Middle Palaeolithic fire: Quaternary International, 315, 3-15.

Márquez, B., Mosquera, M., Pérez-González, A., Arsuaga, J.L., Baquedano, E., Panera, J., Espinosa, J.A., Gómez, J., 2013, Evidence of a Neanderthal-Made Quartz-Based Technology at Navalmaíllo Rockshelter (Pinilla del Valle, Madrid region, Spain): Journal of Anthropological Research, 69, 373-395.

Morales, J., Goguitchaichvili, A., Aguilar-Reyes, B., Pineda-Duran, M., Camps, P., Carvallo C., Calvo-Rathert, M., 2011, Are ceramics and bricks reliable absolute geomagnetic intensity carriers?: Physics of the Earth and Planetary Interiors, 187, 310-321.

Munayco, P., Scorzelli, R.B., 2013, Characterization of the firing conditions of archaeological Marajoara pottery by Mössbauer spectroscopy and X-ray diffraction: Hyperfine Interactions, 222, 69-75.

Özdemir, Ö., Dunlop, D. J., 2000, Intermediate magnetite formation during dehydration of goethite: Earth Planetary Science Letters, 177, 59-67.

Pérez-González, A., Karampaglidis, T., Arsuaga, J. L., Baquedano, E., Bárez, S., Gómez, J. J., Panera, J., Márquez, B., Laplana, C., Mosquera, M., Huguet, R., Sala, P., Arriaza, M. C., Benito, A., Aracil, E., Maldonado, E., 2010, Aproximación geomorfológica a 
los yacimientos del Pleistoceno Superior del Calvero de la Higuera en el Valle Alto del Lozoya (Sistema Central español, Madrid): Zona Arqueológica, 13, 404-420.

Reidsma, F.H., van Hoesel, A., van Os, B.J.H., Megens, L., Braadbaart, F., 2016, Charred bone: Physical and chemical changes during laboratory simulated heating under reducing conditions and its relevance for the study of fire use in archaeology: Journal of Archaeological Science Reports, 10, 282-292.

Rodriguez Ceja, M., Goguitchaichvili, A., Morales, J., Ostrooumov, M., Manzanilla, L., Aguilar Reyes, B., Urrutia-Fucugauchi, J., 2009, Integrated archeomagnetic and micro-Raman spectroscopy study of preColumbian ceramics from the Mesoamerican formative village of Guanalan, Teotihuacan Valley, Mexico: Journal of. Geophysical. Researches., 114, 1-12.

Schmidt, P., Porraz, G., Slodczyk, A., Bellot-gurlet, L., Archer, W., Miller, C.E., 2013, Heat treatment in the South African Middle Stone Age: temperature induced transformations of silcrete and their technological implications: Journal of Archaeological Science, 40, 3519-3531.
Schmidt, P., Porraz, G., Bellot-Gurlet, L., February, E., Ligouis, B., Paris, G., Texier, P.J., Parkington, J.E., Miller, C.E., Nickel, K.G., Conard, N.J., 2015, A previously undescribed organic residue sheds light on heat treatment in the Middle Stone Age: Journal of Human Evolution, 85, 22-34.

Schmidt, P., February, E., Bretzke, K., BellotGurlet, L., 2017, Tempering-residue on heattreated silcrete: an experimental perspective and a potential analytical protocol: Journal of Archaeological Science: Reports, 15, 611-619.

Stahlschmidt, M.C., Miller, C.E., Ligouis, B., Hambach, U., Goldberg, P., Berna, F., Richter, D., Urban, B., Serangeli, J., Conard, N.J., 2015, On the evidence for human use and control of fire at Schoeningen: Journal of Human Evolution, 89, 181-201.

Tauxe, L., Butler, R., Banerjee, S., van der Voo, R., 2010, Essentials of paleomagnetism. San Diego, CA, University of California Press, $512 \mathrm{p}$.

Wadley, L., Prinsloo, L.C., 2014, Experimental heat treatment of silcrete implies analogical reasoning in the Middle Stone Age: Journal of Human Evolution, 70, 49-60. 